\title{
THE PLAY MOTOR ACTIVITY IN THE PRIMARY SCHOOL - IMPLEMENTATION AND PROBLEMS
}

\author{
V. Ivanova* \\ Faculty of Education, Trakia University, Stara Zagora, Bulgaria
}

\begin{abstract}
PURPOSE: The research is provoked by the problems that accompany the implementation of play activities in the forms of motor training in primary school.

METHODS: A survey is conducted among teachers teaching the subject "Physical Education and Sports" in I - IV grade.

RESULTS: The analysis of the answers of the respondents reveals negatives that hinder the effective pedagogical process.

CONCLUSIONS: The following problems are pointed out as the most significant: the insufficient number or technical malfunction of the sports equipment, tools, equipment; limited working space both outdoors and indoors; the lack of clear guidelines and specific guidelines for planning and implementation of educational content in physical education, including games, especially - sports; unclear criteria and standards for assessing the success and progress of students in the game activities; the lack of guidelines for working with students with special educational needs or health problems; insufficient proposed forms, such as seminars, training courses, etc. to acquaint the primary teachers with novelties in the educational process in Physical Education and Sport.
\end{abstract}

Key words: physical education and sport, survey, primary school teachers

\section{INTRODUCTION}

Games with motor performances, classified according to their diverse characteristics mobile, sports-preparatory, sports, recreational, with a corrective effect, etc., are most widely represented in the various forms of physical education and sports in primary school. Their rich motor and emotional content and effects on children's development ensure this indisputable superiority. (1-4)

In a conducted study it has been found that a larger share of school activities aimed at increasing the level of physical activity of students ,achieve success only during the school day". The reason is seen in the excessive focus on motor training and physical capacity of students, which according to the authors of the study does not lead to generating a positive attitude towards physical activity,

\footnotetext{
*Correspondence to: Veselina Ivanova, Faculty of Education, Trakia University, Stara Zagora, Bulgaria, 9 Armeyska str., Faculty of Education, 6010 Stara Zagora, Bulgaria, Mobile: +359885508797,e-mail:v_g_chipeva@abv.bg
}

and hence in the long run - causing behavioral changes. (5)

We consider such an alternative to be the plays whose intransigent necessity pointed out by a number of authors, is especially important for the modern child. (6-9) Today, the child grows up in a "greenhouse environment" caused by the adverse effects of global processes, the IT society and other reasons, demotivating him from an early age for outdoor games, those that bring, among other things, the positives of live communication with peers. (10)

In her publication, I. Ružbarská writes: "Children who receive systematic and effective support in the development of their motor skills are largely adapted to and prepared for successful participation in a wider range of physical activities. This mutually leads to the development of the motor competencies of the individual both from the long-term educational perspective and in the attitude to an active and healthy lifestyle." (11) 
Of course, it is fundamental on a theoretical level to define in different normative documents the goals, objectives, approaches for the implementation of physical education in an institutionally organized environment, but critical for their implementation in practice are the conditions created in school; teachers their education, competence and motivation for carrying out the educational process; parents "embedded" in this process, as well as other, no less important factors. $(12,13)$

\section{METHODS}

Our research is provoked by problems that accompany the implementation of play activities in the forms of motor training in primary school. The survey was conducted in the 2018/2019 school year among 251 primary school teachers, teaching the subject "Physical Education and Sports". 100\% are women, which is no surprise about the trend towards feminization of the teaching profession. (13)

The age of the respondents varies from 21 to 65 years, with the largest share $(70 \%)$ of those, at the age between 41 and 65 years. Almost half of the respondents $(47 \%)$ have over twenty years of teaching experience. About $7 \%$ are those with up to 5 years of practice in school, which confirms the unfavorable aging process of the teaching profession.

The largest group consists of teachers working in large cities - 62\%. The other part of the respondents works in small towns and villages. All surveyed teachers have higher education master $(83 \%)$ or bachelor degree $(17 \%)$.

A modified version of the questionnaire was used for the study. (14) It contains both closedended questions with a variety of answers and questions with answers on the Likert scale from 1 to 4 ( 1 - the lowest level and 4 - the highest one) to assess the different levels of the consent of the surveyed teachers, regarding the aspects of the condition and realization of the subject "Physical Education and Sports" in primary school. The questions in the questionnaire are presented in four sections. Some of the items are focused on gaming motor activity.

\section{RESULTS}

IVANOVA $V$.

The first section of the questionnaire includes questions related to sports facilities in the school. The summarized results show that outdoor sports facilities (sports grounds, playgrounds, etc.) are used for conducting various forms of physical education, regardless of whose property they are. In $47 \%$ of the cases, this is the park or other suitable area located near the school.

It is worrying that balls, sticks, hoops, ropes and other sports equipment are used simultaneously in $49 \%$ of cases for motor training of primary school students and students in upper grades. $6 \%$ of the surveyed teachers report that the school's sports equipment is extremely insufficient to cover the motor training needs of all students in the school, so they are used only to provide the learning process in physical education and sports in the upper grades.

In the 2018/2019 school year, slightly more than half of the surveyed teachers (64\%) used the gym alone with their class to conduct the form of motor training. $18 \%$ of the respondents had worked simultaneously with another class of primary school age. $12 \%$ of the respondents report that during the lesson in Physical Education and Sport the gym is shared between a class of primary school age and a class of lower secondary education. $6 \%$ of primary school teachers are not given the opportunity to conduct training in the school gym. This means that when the weather conditions are unsuitable for outdoor work, children of primary school age do not conduct lessons and other forms of physical education and sport.

To solve the educational, upbringing and healing tasks in the forms of motor training, the teachers teaching physical education are free in their choice of pedagogical means, procedures and methods. The following questions in the questionnaire directly correspond to the conditions for conducting the forms of motor training in primary school. Table 1 shows that the answers given by the teachers: "I agree" and "I completely agree" prevail over those of the first two columns. 
IVANOVA $V$.

Table 1. Questions related to the conditions for conducting the forms of motor training in the primary school (in numbers and in percentages)

\begin{tabular}{|c|c|c|c|c|}
\hline 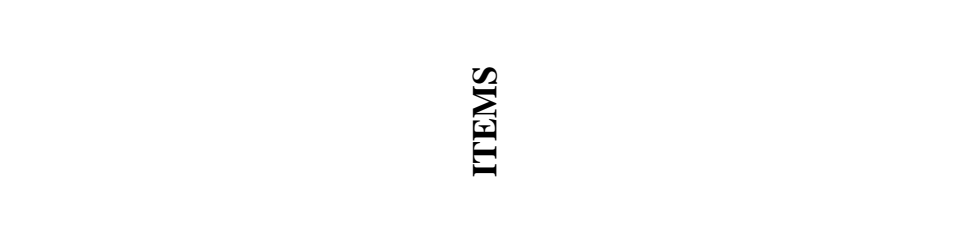 & 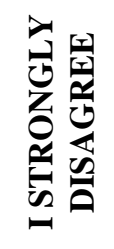 & 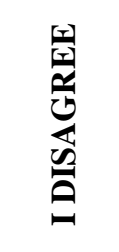 & 空 & 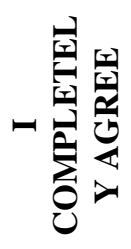 \\
\hline $\begin{array}{l}\text { 1. The spatial conditions at our disposal perfectly satisfy the needs } \\
\text { of my class for the effective implementation of the motor training. }\end{array}$ & $\begin{array}{r}118 \\
47 \%\end{array}$ & $\begin{array}{c}88 \\
35,1 \%\end{array}$ & $\begin{array}{c}45 \\
17,9 \%\end{array}$ & - \\
\hline $\begin{array}{l}\text { 2. Sports equipment at our disposal (beam, gym wall, gym bench, } \\
\text { etc.) perfectly satisfies the needs of my class for the effective } \\
\text { implementation of the forms of Physical education and sport. }\end{array}$ & $\begin{array}{c}132 \\
52,6 \%\end{array}$ & $\begin{array}{c}29 \\
11,5 \%\end{array}$ & $\begin{array}{c}45 \\
17,9 \%\end{array}$ & $\begin{array}{c}45 \\
17,9 \%\end{array}$ \\
\hline $\begin{array}{l}\text { 3. The tools (balls, sticks, hoops, dumb-bells, ropes, etc.) perfectly } \\
\text { satisfy the needs of my class for the effective implementation of the } \\
\text { Physical education and sport lessons. }\end{array}$ & $\begin{array}{c}103 \\
41,1 \% \\
\end{array}$ & $\begin{array}{c}58 \\
23,1 \%\end{array}$ & $\begin{array}{c}45 \\
17,9 \%\end{array}$ & $\begin{array}{c}45 \\
17,9 \%\end{array}$ \\
\hline $\begin{array}{l}\text { 4. In cases, when there are no suitable conditions for the } \\
\text { implementation of a Physical education and sport lesson in a gym } \\
\text { or on an outdoor sports field, it is held in the classroom. }\end{array}$ & - & $\begin{array}{c}102 \\
40,6 \%\end{array}$ & $\begin{array}{c}103 \\
41,1 \%\end{array}$ & $\begin{array}{c}46 \\
18,3 \%\end{array}$ \\
\hline $\begin{array}{l}\text { 5. It is better the Physical education and sport lesson to be held in } \\
\text { the study-room or other adapted premises than not to take place at } \\
\text { all. }\end{array}$ & $\begin{array}{r}118 \\
47 \%\end{array}$ & $\begin{array}{c}46 \\
18,3 \%\end{array}$ & $\begin{array}{c}46 \\
18,3 \%\end{array}$ & $\begin{array}{c}41 \\
16,4 \%\end{array}$ \\
\hline
\end{tabular}

As it can be seen from the answers in the following table (Table 2), presented in numbers and percentages, more often the general equipment and tools are used by the students in the classes following the primary level of education.

Table 2. Use of common sports equipment at school

\begin{tabular}{|c|c|c|c|c|}
\hline$\sum_{=}^{\infty}$ & $\frac{n}{2}$ & 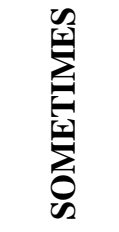 & 孬 & $\frac{2}{3}$ \\
\hline $\begin{array}{l}\text { 1. The sports equipment in our school is used by all classes of } \\
\text { primary school age for the implementation of the Physical } \\
\text { Education and sport lessons. }\end{array}$ & - & $\begin{array}{c}102 \\
40,6 \%\end{array}$ & $\begin{array}{c}75 \\
29,9 \%\end{array}$ & $\begin{array}{c}74 \\
29,5 \%\end{array}$ \\
\hline $\begin{array}{l}\text { 2. The sports equipment in our school is used by all classes of } \\
\text { primary school age for the implementation of the motor } \\
\text { training, as well as for the Physical education and sport lessons } \\
\text { of the upper-age students (after 5th grade). }\end{array}$ & $\begin{array}{l}75 \\
29,9 \%\end{array}$ & $\begin{array}{l}75 \\
29,9 \%\end{array}$ & $\begin{array}{c}56 \\
22,3 \%\end{array}$ & $\begin{array}{c}45 \\
17,9 \%\end{array}$ \\
\hline $\begin{array}{l}\text { 3. If there is a possibility for a choice, teachers, Physical } \\
\text { education professionals give preference to the use of the } \\
\text { common sports equipment by primary school students. }\end{array}$ & $\begin{array}{c}29 \\
11,5 \%\end{array}$ & $\begin{array}{c}75 \\
29,9 \%\end{array}$ & $\begin{array}{c}103 \\
41,1 \%\end{array}$ & $\begin{array}{c}44 \\
17,5 \%\end{array}$ \\
\hline $\begin{array}{l}\text { 4. For the implementation of the Physical education and sport } \\
\text { lessons I use my personal sports tools, when necessary. }\end{array}$ & $\begin{array}{c}45 \\
17,9 \%\end{array}$ & $\begin{array}{c}132 \\
52,7 \%\end{array}$ & $\begin{array}{c}45 \\
17,9 \%\end{array}$ & $\begin{array}{c}29 \\
11,5 \%\end{array}$ \\
\hline $\begin{array}{l}\text { 5. For the implementation of the Physical education lessons at } \\
\text { school my students bring personal sports tools, when necessary. }\end{array}$ & $\begin{array}{c}45 \\
17,9 \%\end{array}$ & $\begin{array}{c}161 \\
64,2 \%\end{array}$ & $\begin{array}{c}45 \\
17,9 \%\end{array}$ & - \\
\hline $\begin{array}{l}\text { 6. In the absence of enough devices and tools, during the } \\
\text { Physical education lesson I use non-standard ones (stool, table, } \\
\text { bag, elastic band, bottle of water, cloth, etc.). }\end{array}$ & $\begin{array}{c}29 \\
11,5 \%\end{array}$ & $\begin{array}{c}147 \\
58,6 \%\end{array}$ & $\begin{array}{c}75 \\
\mathbf{2 9 , 9 \%}\end{array}$ & - \\
\hline $\begin{array}{l}\text { 7. When the curricula allow this, I prefer to implement my PE } \\
\text { lessons outdoors. }\end{array}$ & - & $\begin{array}{c}17 \\
6,8 \%\end{array}$ & $\begin{array}{c}102 \\
40,6 \%\end{array}$ & $\begin{array}{r}132 \\
52,6 \%\end{array}$ \\
\hline
\end{tabular}

Section two of the survey discusses the current programs in physical education and sports, their implementation. The share of teachers who participated in the survey is very high, who, despite their long professional experience as a primary school teacher, do not make 
interdisciplinary links in motor learning with other subjects - this is $1 / 3$ of all cases.

The use of active PE games in the lesson of Physical Education and Sport offers rich opportunities for the implementation of the interdisciplinary approach in education. The connection with the subjects Mathematics, Man and Nature, Man and Society, Art, etc. is close. The training allows to use various in shapes and sizes geometric figures, measuring time in seconds and minutes, distance in centimetres and metres, etc., to enrich students' knowledge of the human body and the impact of exercise on its development and health condition.

The next question in this section of the survey aims to clarify the extent to which primary school teachers use mobile games in the main form of physical education - the lesson. As can be seen from the table, the answers "sometimes" and "often" prevail (Table 3).

Table 3. Use of active PE games in the Physical Education and Sport lesson

\begin{tabular}{|c|c|c|c|c|}
\hline$\sum_{\text {空 }}$ & 孚 & 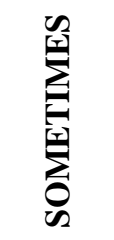 & $\frac{Z}{0}$ & $\frac{2}{3}$ \\
\hline $\begin{array}{l}\text { 1. I apply active games in the preparatory part of the PE } \\
\text { lesson. }\end{array}$ & - & $\begin{array}{c}161 \\
64,2 \%\end{array}$ & $\begin{array}{c}45 \\
17,9 \%\end{array}$ & $\begin{array}{c}45 \\
17,9 \%\end{array}$ \\
\hline 2. I apply active games in the main part of the PE lesson. & $\begin{array}{c}7 \\
\mathbf{2 , 9 \%}\end{array}$ & $\begin{array}{c}45 \\
17,9 \%\end{array}$ & $\begin{array}{c}161 \\
64,2 \%\end{array}$ & $\begin{array}{c}38 \\
15 \%\end{array}$ \\
\hline 3. I apply active games in the final part of the PE lesson. & $\begin{array}{c}19 \\
7,7 \%\end{array}$ & $\begin{array}{c}119 \\
47,4 \%\end{array}$ & $\begin{array}{c}75 \\
29,9 \%\end{array}$ & $\begin{array}{c}38 \\
15 \%\end{array}$ \\
\hline $\begin{array}{l}\text { 4. When there is an opportunity, I apply Bulgarian folk games } \\
\text { during the PE lesson. }\end{array}$ & - & $\begin{array}{c}119 \\
47,3 \% \\
\end{array}$ & $\begin{array}{c}125 \\
49,8 \% \\
\end{array}$ & $\begin{array}{c}7 \\
2,9 \% \\
\end{array}$ \\
\hline 5. In the PE lesson, I use musical active games. & - & $\begin{array}{r}118 \\
47 \%\end{array}$ & $\begin{array}{r}118 \\
47 \%\end{array}$ & $\begin{array}{l}15 \\
6 \%\end{array}$ \\
\hline $\begin{array}{l}\text { 6. I use active games as a form of active recovery (physical } \\
\text { pause) in other subjects lessons. }\end{array}$ & - & $\begin{array}{c}125 \\
49,8 \%\end{array}$ & $\begin{array}{c}103 \\
41,1 \%\end{array}$ & $\begin{array}{c}23 \\
9,1 \%\end{array}$ \\
\hline
\end{tabular}

The third section of the survey comments on the most common problems and difficulties in the implementation of motor training in school. Almost equally, the respondents indicate that they do not encounter difficulties - $41 \%$ of them or that they are insignificant, typical of the learning process in the implementation of the game activity. For $6 \%$ of the respondents, the problems can be overcome with a little help and external intervention. There are just as many who say that systematic external intervention and significant changes are needed to overcome the problems that have arisen.

The fourth section of the survey addresses issues related to innovation and the need for changes in current Physical Education and sport programs for primary school (Table 4). $65 \%$ of the surveyed teachers accept and like the programs in physical education and sports. The percentage of those who cannot determine is high. In second place is the answer "I do not know / I'm not sure / sure" - 30\%. 6\% of teachers believe that significant changes are needed. The view of the surveyed primary teachers on this problem is reflected in tabular form.

$24 \%$ of the respondents believe that they have sufficient knowledge in the field of theory and methodology of physical education, acquired during their studies in higher education, to conduct an effective learning process. 53\% believe that although they are sufficient, it is necessary to monitor trends and changes. Almost $1 / 4$ state that they encountered difficulties at the beginning of their career as a teacher. That is why almost half of the respondents think that they need additional qualification, trainings or seminars on the theory and methodology of physical education in order to be in sync with the novelties in the work $-47 \%$; to upgrade what has been mastered / supplement what was missed in the Faculty of Pedagogy - organizational forms, creative approaches to work, ICT, etc. Almost $1 / 4$ would postpone the training at this stage. 
Table 4. Need for changes in Physical Education and sport curricula according to the surveyed teachers

\begin{tabular}{|c|c|c|c|c|}
\hline 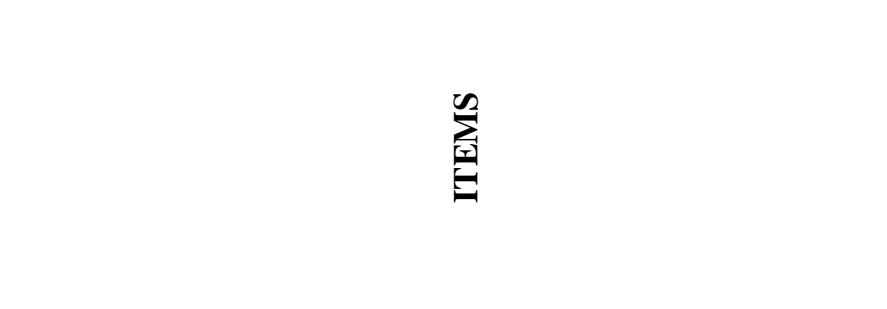 & 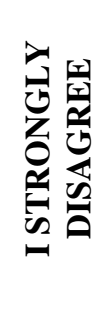 & 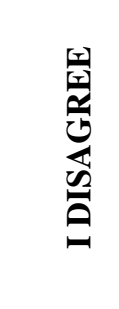 & 空 & 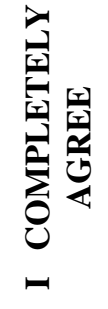 \\
\hline $\begin{array}{l}\text { 1. Bigger share of the main forms of movement (walking, } \\
\text { running, jumping, crawling, etc.), fixed combinations and } \\
\text { active games in the curricula for grades I and II. }\end{array}$ & - & $\begin{array}{c}45 \\
17,9 \% \\
\end{array}$ & $\begin{array}{l}161 \\
64,2\end{array}$ & $\begin{array}{c}45 \\
17,9 \% \\
\end{array}$ \\
\hline $\begin{array}{l}\text { 2. Bigger share of the main forms of movement (walking, } \\
\text { running, jumping, crawling, etc.), fixed combinations and } \\
\text { active games in the curricula for grades III and IV. }\end{array}$ & $\begin{array}{l}15 \\
6 \%\end{array}$ & $\begin{array}{c}45 \\
17,9 \%\end{array}$ & $\begin{array}{l}161 \\
64,2\end{array}$ & $\begin{array}{c}30 \\
11,9 \%\end{array}$ \\
\hline $\begin{array}{l}\text { 3. Broader comprisal of specific sports in the curricular for } \\
\text { grades I and II. }\end{array}$ & $\begin{array}{l}15 \\
6 \% \\
\end{array}$ & $\begin{array}{c}45 \\
17,9 \% \\
\end{array}$ & $\begin{array}{c}191 \\
76,1 \% \\
\end{array}$ & - \\
\hline $\begin{array}{l}\text { 4. Broader comprisal of specific sports in the curricula for } \\
\text { grades III and IV. }\end{array}$ & $\begin{array}{l}15 \\
6 \%\end{array}$ & $\begin{array}{l}15 \\
6 \%\end{array}$ & $\begin{array}{c}176 \\
70,1 \%\end{array}$ & $\begin{array}{c}45 \\
17,9 \%\end{array}$ \\
\hline $\begin{array}{l}\text { 5. Introduction of new popular sports disciplines in a hall for } \\
\text { grades I and II. }\end{array}$ & $\begin{array}{r}15 \\
6 \% \\
\end{array}$ & $\begin{array}{c}30 \\
11,9 \% \\
\end{array}$ & $\begin{array}{c}191 \\
76,1 \% \\
\end{array}$ & $\begin{array}{l}15 \\
6 \% \\
\end{array}$ \\
\hline $\begin{array}{l}\text { 6. Introduction of new population sports disciplines in a hall } \\
\text { for grades III and IV. }\end{array}$ & $\begin{array}{l}15 \\
6 \% \\
\end{array}$ & $\begin{array}{c}30 \\
11,9 \% \\
\end{array}$ & $\begin{array}{c}191 \\
76,1 \% \\
\end{array}$ & $\begin{array}{l}15 \\
6 \% \\
\end{array}$ \\
\hline $\begin{array}{l}\text { 7. Introduction of new outdoor sports activities, close to nature } \\
\text { in grades I and II. }\end{array}$ & $\begin{array}{r}15 \\
6 \%\end{array}$ & $\begin{array}{c}176 \\
70,1 \%\end{array}$ & $\begin{array}{c}60 \\
23,9 \%\end{array}$ & - \\
\hline
\end{tabular}

According to the respondents, the inclusion of physical education specialists in the educational process in physical education and sports at the National School of Physical Education is:

$\checkmark$ Possibly, as conducting motor training of students entirely by the specialist $-59 \%$.

$\checkmark$ Possible, but as associates / assistants to primary teachers $-30 \%$.

$\checkmark$ Possibly, as associates of primary teachers, but for teaching a certain section of physical education and sports $-11 \%$.

This trend is already visible. In many schools in grades III and IV, Physical Education and Sport lessons are taught by specialists.

\section{CONCLUSIONS}

Part of the educational content in the physical education program is not consistent with the professional training of the primary school teacher to carry out play activities in the process of motor training at school.

The following problems were identified as significant in the study:

$\checkmark$ the insufficient number or technical malfunction of the sports equipment, tools, equipment;

$\checkmark$ limited working space - both outdoors and indoors; $\checkmark$ the lack of clear guidelines and specific guidelines for planning and implementation of educational content in physical education, including games, especially - sports;

$\checkmark$ unclear criteria and standards for assessing the success and progress of students in the game activities;

$\checkmark$ the lack of guidelines for working with students with special educational needs or health problems; insufficient proposed forms, such as seminars, training courses, etc. to acquaint the primary teachers with novelties in the educational process in Physical Education and Sport.

\section{REFERENCES}

1. Ivanova, V., Module „Games" in the training of physical education and sports in 1.-4. Class. St. Zagora, Izd. Trakia University, 2010.

2. Tomova, D., Extracurricular activities in physical education and sports University Publishing House "Neofit Rilski", Blagoevgrad, 2013.

3. Chernev, V1., Lyubenova, D., Ivanova, G. and Mavrudieva, N., The influence of mobile games on the development of some motor skills in second grade students. 
Sports \& Science, XLVII, 6, 124-128, 2007.

4. Peneva, P. and Simeonov, K., The playful nature of the education in physical education and sports - a factor for the complex development of adolescents. Scientific works of the University of Ruse, volume 49, series 8.2, 108-112, 2010.

5. https://notonlyfairplay.pixelonaline.org/files/toolkit/Toolkit_BG_SHD0 4.pdf).

6. Aleksieva, M. and Petkova, M., Green light for games. V. Tarnovo: Faber, 2014.

7. Ilieva I., The motivation for sports in primary school age. Ruse, Izd. center at RU "A. Kanchev", 2012.

8. Petkova, M. and Aleksieva, M., Games in the primary school, V. Tarnovo: Faber, 2013.

9. Popeska, B. and Jovanova-Mitkovska, Sn., Traditional games in primary school curriculum. International Journal Knowledge, 16 (4). pp. 1548-1555, 2017.

10.Ivanova, V. and Kartselyanska - Stancheva, V., Modern metamorphoses of the relationships in the children's group. Pedagogy, NION ,Az-buki“, vol. 90, № 2 pp. $184-193,2018$.
IVANOVA $V$.

11.Ružbarská, I., Physical Fitness of Children with Different Levels of Motor Coordination. 1st FIEP Afro-European Conference on Physical Education and Sport, 25th FIEP World Congress 10th FIEP European Congress. Physical Education and Sport for Peace, Development and Multicultural Understanding, Book Proceeding, Bratislava, 208-212, 2016.

12.Mileva, E., The professional training in physical education and sports of the teachers in the initial stage of the basic educational degree. Sports \& Science, 62 (4), $106-114,2018$.

13.Ivanova, V. and Mileva, E., Factors of the satisfaction of the primary teachers from the professional activity. Pedagogy, NION Az-buki, year XCII, book 5, pp. 688 - 702, 2020.

14.Klincarov, Il., Popeska, B., Mitevski, Or., Nikovski, G., Mitevska - Petrusheva, K., Majeric, M., Tandem Teaching in Physical and Health Education Classes from Teacher'S Perspective Research in Physical Education, Sport and Health Vol.7, No.1, pp.109-115, 2018. 